\section{BIVENTRICULAR REPAIR IN CARDIAC ISOMERISM}

\section{Report of seventeen cases}

From the Division of Cardiovascular Surgery, National Cardiovascular Center, Osaka, Japan.

Received for publication July 9, 1993.

Accepted for publication August 26, 1994.

Address for reprints: Kazunobu Hirooka, MD, Tsuchiura Kyodo General Hospital, Manabeshinnmachi, 11 Tsuchiura, Ibaraki, 300, Japan.

Copyright $(\mathcal{C} 1995$ by Mosby-Year Book, Inc.

$0022-5223 / 95 \$ 3.00+0 \quad \mathbf{1 2} / \mathbf{1} / 60249$
Ninety-three patients with cardiac isomerism were treated surgically from July 1985 to June 1991. Among them, three patients with right and 14 with left isomerism underwent biventricular repair. Ages ranged from 4 months to 41 years (mean 4.8 years). Anatomic repair was accomplished in 15 patients and functional repair with the right ventricle used as the systemic ventricle in two patients. Methods of atrial septation to separate pulmonary venous flow from systemic venous flow included atrial partition with a straight patch in seven patients, intraatrial rerouting with a tailored baffle in five, and a Mustard-type atrial switch in five. One hospital death (5.8\%) and two late deaths $(12 \%)$ occurred. Two patients required reoperation (12\%), one reconstruction of a stenotic systemic venous connection and one mitral valve replacement because of incompetence. Surgically induced complete atrioventricular block was not observed in any of the patients. Optimal atrial septation offers the possibility of biventricular repair for patients with acceptable intraventricular structure. (J THORAC CARDIOvasC SURG 1995;109:530-5)

Kazunobu Hirooka, MD, Toshikatsu Yagihara, MD, Hirofumi Kishimoto, MD, Fumitaka Isobe, MD, Fumio Yamamoto, MD, Kyoichi Nishigaki, MD, Osamu Matsuki, MD, Hideki Uemura, MD, and Yasunaru Kawashima, MD, Osaka, Japan
A trial isomerism is recognized as a cardiovascular anomaly associated with asplenia (right isomerism) and polysplenia (left isomerism) ${ }^{1-6}$ It has been reported that $79 \%$ of patients with right isomerism and $61 \%$ with left isomerism die of cardiac failure or anoxia by the end of their first year. ${ }^{4}$ Naturally, surgical treatment is complicated by the extent and variability of intracardiac anomalies. Here we report information on 17 patients with cardiac isomerism who underwent biventricular repair.

\section{Patients and methods}

Ninety-three patients with cardiac isomerism underwent surgical treatment between July 1985 and June 1991 at the National Cardiovascular Center. Three of 61 patients with right isomerism (5\%) and 14 of 32 patients with left isomerism (44\%) underwent biventricular repair. The mean age of these 17 patients at operation was 4.8 years.

Isomerism status was determined before the operation on the basis of identification of thoracic isomerism, and the structure of the atrial appendages was identified during the operation. The thoracic situs was determined on the basis of the relationship between the bronchi and pulmonary arteries. For example, short eparterial bronchi on plain chest radiograph or angiogram was diagnosed as right isomerism and long hyparterial bronchi as left isomerism. $^{7-9}$

Morphologic findings are summarized in Table I. Among those with right isomerism, patients 2 and 3 had a double-outlet right ventricle; the ventricular septal defect (VSD) was noncommitted in one and subaortic in the other. Patient 2 had a common atrium and patients 1 and
3 had an atrioventricular septal defect (AVSD). Patients 2 and $3 \mathrm{had}$ infundibular pulmonary stenosis and patient 1 had a stenotic bicuspid pulmonary valve. Total anomalous pulmonary venous connections were present in two patients.

AVSDs were found in eight patients with left isomerism; the incomplete form was present in five and the complete form in the other three patients. Among the other six patients, four had an atrial septal defect, one had a common atrium, and another had a patent foramen ovale. Bilateral superior venae cavae were present in eight patients; azygos or hemiazygos connection and absence of the inferior vena cava were noted in nine patients. Three patients had corrected transposition of the great arteries (TGA) with pulmonary atresia in two and stenosis in one. In previous operations, systemic-pulmonary shunts had been constructed in five and pulmonary artery banding had been performed in three patients. A persistent ductus arteriosus had been ligated as well in patient 15 .

Operations were performed with extracorporeal circulation, moderate hypothermia, and cold chemical cardioplegic arrest. A crystalloid cardioplegic solution was given at an initial dose of $10 \mathrm{ml} / \mathrm{kg}$ and then at a dose of $5 \mathrm{ml} / \mathrm{kg}$ every 30 minutes. All surgical shunts were ligated at the beginning of bypass. Extracorporeal circulation time ranged from 85 to 379 minutes (mean 238 minutes) and aortic crossclamping time from 38 to 171 minutes (mean 119 minutes).

Right isomerism. Patient 1 had TGA combined with pulmonary stenosis and an intact ventricular septum; therefore he needed the right ventricle to serve as the systemic ventricle. Atrial septation was performed according to the method of Mustard. Equine pericardium was used for a pantaloon-shaped intraatrial baffle and for an 
Table I. Surgical experience with right and left isomerism

\begin{tabular}{|c|c|c|c|c|c|}
\hline $\begin{array}{l}\text { Patient } \\
\text { No. }\end{array}$ & $\begin{array}{l}\text { Age, } \\
\text { sex }\end{array}$ & Cardiovascular anomalies & Surgical treatment & $\begin{array}{l}\text { Previous } \\
\text { operation }\end{array}$ & Result \\
\hline \multicolumn{6}{|l|}{ Right } \\
\hline 1 & $5 \mathrm{yr}, \mathrm{M}$ & $\begin{array}{l}\text { AVSD incomp., TGA, PS, Bil. } \\
\text { SVC, left IVC, severe MR, TR }\end{array}$ & $\begin{array}{l}\text { Mustard + TVR, pulmonary } \\
\text { valvotomy }\end{array}$ & None & Alive \\
\hline 2 & $6 \mathrm{yr}, \mathrm{F}$ & $\begin{array}{l}\text { DORV, CA, PS, TAPVC (1a), } \\
\text { left IVC, single coronary }\end{array}$ & $\begin{array}{l}\text { IAR + LV-Ao IC repair, } \\
\text { RV-PA EC repair, com- } \\
\text { mon PV-CA anastomosis }\end{array}$ & B-T shunt & Alive \\
\hline 3 & $5 \mathrm{yr}, \mathrm{M}$ & $\begin{array}{l}\text { AVSD comp., DORV, PS, } \\
\text { TAPVC (1a) }\end{array}$ & $\begin{array}{l}\text { Two-patch method (IAR + } \\
\text { LV-Ao IC repair), infundi- } \\
\text { bulectomy }\end{array}$ & None & Alive \\
\hline \multicolumn{6}{|c|}{ 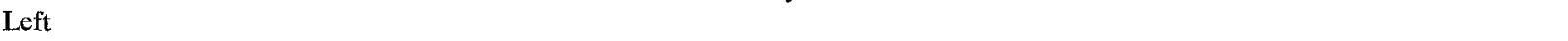 } \\
\hline 4 & $1 \mathrm{yr}, \mathrm{M}$ & $\begin{array}{l}\text { Dextrocardia, AVSD incomp., } \\
\text { left SVC, hemiazygos connec- } \\
\text { tion, second-degree AV block }\end{array}$ & Mustard, pacemaker implant & None & $\begin{array}{l}\text { Alive, reoperation: patch en- } \\
\text { largement of SVC and IVC } \\
40 \text { months postop. }\end{array}$ \\
\hline 5 & $6 \mathrm{yr}, \mathrm{M}$ & $\begin{array}{l}\text { Corrected TGA, VSD, ASD, PS, } \\
\text { Bil. SVC, right aortic arch }\end{array}$ & $\begin{array}{l}\text { ASD patch closure, LV-PA } \\
\text { EC repair }\end{array}$ & $\begin{array}{l}\text { B-T shunt, } \\
\text { central } \\
\text { shunt }\end{array}$ & $\begin{array}{l}\text { Died of arrhythmia suspected } \\
18 \text { mo postop. }\end{array}$ \\
\hline 6 & $13 \mathrm{yr}, \mathrm{M}$ & $\begin{array}{l}\text { Dextrocardia, TF, ASD, PAPVC, } \\
\text { Bil. SVC, right aortic arch, } \\
\text { hemiazygos connection }\end{array}$ & IAR, RVOTR & Central shunt & $\begin{array}{l}\text { Died of LV dysfunction } 1 \text { day } \\
\text { postop. }\end{array}$ \\
\hline 7 & $1 \mathrm{yr}, \mathrm{M}$ & $\begin{array}{l}\text { AVSD incomp., azygos connec- } \\
\text { tion, third-degree AV block }\end{array}$ & $\begin{array}{l}\text { Atrial partition, pacemaker } \\
\text { implant }\end{array}$ & None & Alive \\
\hline 8 & $3 \mathrm{yr}, \mathrm{M}$ & $\begin{array}{l}\text { Dextrocardia, corrected TGA, } \\
\text { VSD, PFO, PA }\end{array}$ & $\begin{array}{l}\text { Double switch (Mustard }+ \\
\text { LV-Ao IC repair), RV-PA } \\
\text { EC repair }\end{array}$ & Bil. B-T shunt & Alive \\
\hline 9 & $3 \mathrm{yr}, \mathrm{M}$ & $\begin{array}{l}\text { AVSD comp., TF, Bil. SVC, } \\
\text { hemiazygos connection, third- } \\
\text { degree AV block }\end{array}$ & $\begin{array}{l}\text { Two-patch method (IAR + } \\
\text { VSD closure), RVOTR, } \\
\text { pacemaker implant }\end{array}$ & None & Alive \\
\hline 10 & $3 \mathrm{yr}, \mathrm{M}$ & $\begin{array}{l}\text { AVSD comp., severe regurgita- } \\
\text { tion of common AV valve }\end{array}$ & $\begin{array}{l}\text { Two-patch method (atrial } \\
\text { partition + VSD closure) }\end{array}$ & PA banding & $\begin{array}{l}\text { Alive, reoperation: MVR } 17 \\
\text { days postop. }\end{array}$ \\
\hline 11 & $1 \mathrm{yr}, \mathrm{M}$ & $\begin{array}{l}\text { AVSD incomp., Bil. SVC, azygos } \\
\text { connection }\end{array}$ & $\begin{array}{l}\text { Atrial partition, ligation of } \\
\text { left SVC }\end{array}$ & None & Alive \\
\hline 12 & $3 \mathrm{yr}, \mathrm{M}$ & $\begin{array}{l}\text { Corrected TGA, VSD, PA, ASD, } \\
\text { Bil. SVC, left IVC }\end{array}$ & $\begin{array}{l}\text { Double switch (Mustard + } \\
\text { LV-Ao IC repair) }\end{array}$ & B-T shunt & Alive \\
\hline 13 & $41 \mathrm{yr}, \mathrm{M}$ & ASD, PS, azygos connection & $\begin{array}{l}\text { ASD patch closure, infundi- } \\
\text { bulectomy }\end{array}$ & None & Alive \\
\hline 14 & $1 \mathrm{yr}, \mathrm{F}$ & $\begin{array}{l}\text { AVSD incomp., Bil. SVC, hemi- } \\
\text { azygos connection }\end{array}$ & $\begin{array}{l}\text { Atrial partition, patch en- } \\
\text { largement of PA, ligation } \\
\text { of right SVC }\end{array}$ & PA banding & Alive \\
\hline 15 & $4 \mathrm{mo}, \mathrm{F}$ & $\begin{array}{l}\text { AVSD comp., Bil. SVC, hemi- } \\
\text { azygos connection, severe re- } \\
\text { gurgitation of common AV } \\
\text { valve }\end{array}$ & $\begin{array}{l}\text { Two-patch method (IAR + } \\
\text { VSD closure) }\end{array}$ & $\begin{array}{l}\text { PA banding, } \\
\text { PDA liga- } \\
\text { tion }\end{array}$ & $\begin{array}{l}\text { Died of infection } 3 \text { mo } \\
\text { postop. }\end{array}$ \\
\hline 16 & $3 \mathrm{yr}, \mathrm{F}$ & $\begin{array}{l}\text { AVSD incomp., Bil. SVC, left } \\
\text { IVC }\end{array}$ & Mustard & None & Alive \\
\hline 17 & $30 \mathrm{yr}, \mathrm{M}$ & $\begin{array}{l}\text { Dextrocardia, CA, left SVC, } \\
\text { hemiazygos connection, atrial } \\
\text { fibrillation }\end{array}$ & Atrial partition & None & Alive \\
\hline
\end{tabular}

AVSD, Atrioventricular septal defect; incomp., incomplete; $T G A$, transposition of the great arteries; $P S$, pulmonary stenosis; $B i l$, bilateral; $S V C$, superior vena cava; $I V C$, inferior vena cava; $M R$, mitral regurgitation; $T R$, tricuspid regurgitation; $D O R V$, double-outlet right ventricle; $C A$, common atrium; TAPVC, total anomalous pulmonary venous connection; comp., complete; $A V$, atrioventricular; $V S D$, ventricular septal defect; $A S D$, atrial septal defect; $T F$, tetralogy of Fallot; $P A P V C$, partial anomalous pulmonary venous connection; $P F O$, patent foramen ovale; $P A$, pulmonary atresia; $T V R$, tricuspid valve replacement; $L A R$, intraatrial rerouting; $L V-A o$, left ventricle-aorta; $I C$, internal conduit; $R V-P A$, right ventricle-pulmonary artery; $P V$, pulmonary vein; $E C$, external conduit; RVOTR, right ventricular outflow tract reconstruction; $B T$, Blalock Taussig; $P A$ banding, pulmonary artery banding; $P D A$, persistent ductus arteriosus.

atriotomy patch to increase the volume of the newly constructed left atrium. Concomitantly, a prosthetic valve for an incompetent right-sided atrioventricular (AV) valve was replaced. In two patients with double-outlet right ventricle, an internal conduit of duplicated equine pericardium was patched to allow drainage of blood from the left ventricle through the VSD and into the aorta. In patient 2 , the noncommitted type VSD was enlarged by 


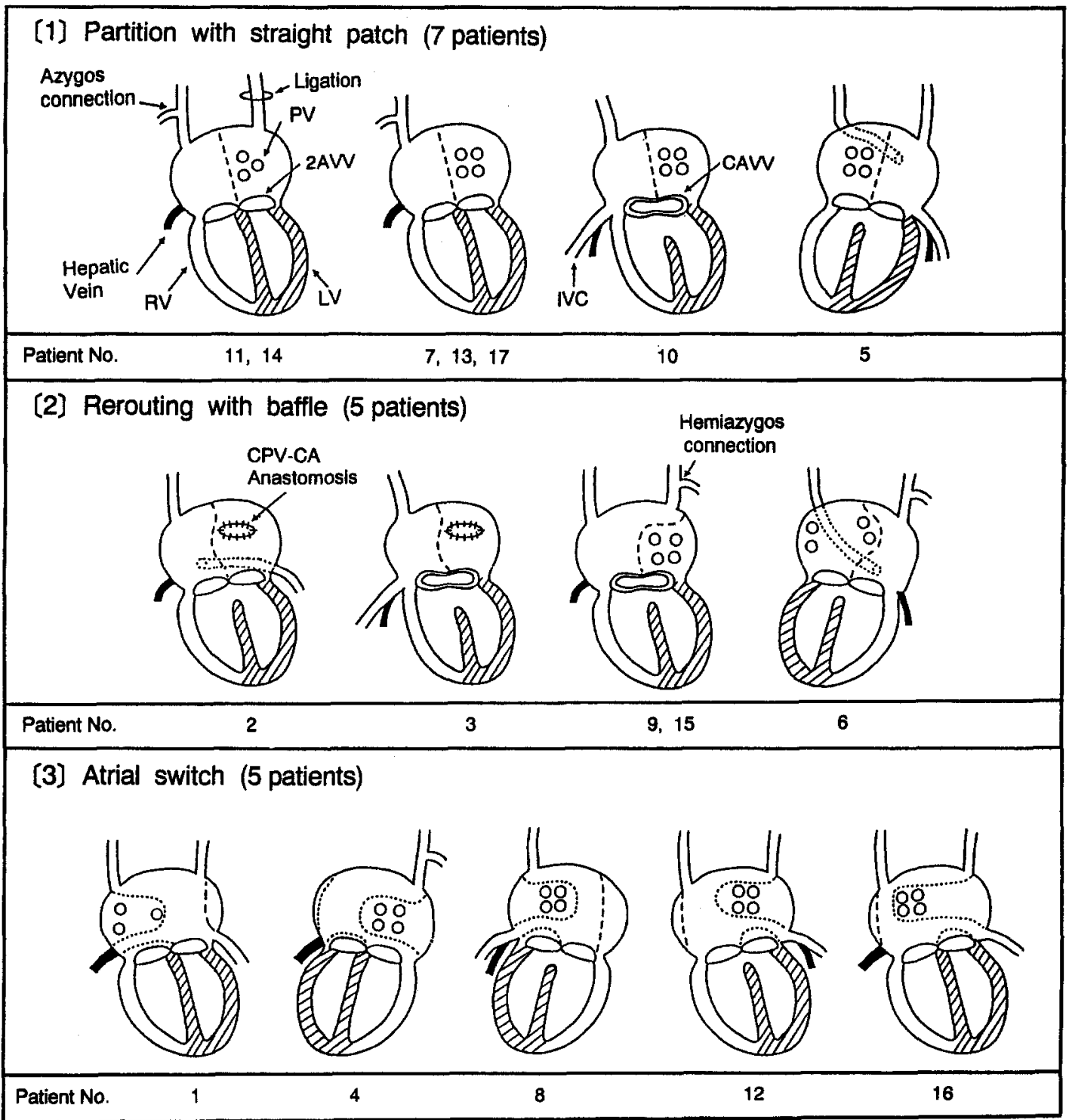

Fig. 1. Atrial septation of isomerism hearts. 1, When systemic and pulmonary veins drained into either side of the atrium independently, a simple atrial partition with a straight patch was used in seven patients. 2, Five patients required intraatrial rerouting with a tailored baffle to separate the pulmonary veins from systemic veins. 3, Atrial switch like Mustard operation was required in five patients because the pulmonary veins drained into the functional right atrium or more than two systemic veins drained into the functional left atrium. $2 A V V$, Two atrioventricular valves; $C A V V$, common atrioventricular valve; $C P V-C A$, common pulmonary vein-common atrium; $L V$, left ventricle; $R V$, right ventricle; $P V$, pulmonary vein.

resecting the muscle bar between the VSD and the aortic valve, where no tricuspid subvalvular component was attached. Because patient 2 had a single coronary artery whose branch ran across the right ventricular outflow, an external conduit repair from the right ventricle to the pulmonary artery was required. In patient 3 , intraatrial rerouting was performed according to the two-patch method with a tailored baffle after total anomalous pulmonary venous connection was repaired by anastomosing the common pulmonary vein to the common atrium followed by ligation of the vertical vein (Fig. 1).

Left isomerism. Intraoperative epicardial mapping to identify the sinus node was performed in nine patients with left isomerism after 1988. Methods of cannulation, atriotomy, and intraatrial suture line were decided on the basis of this investigation. The sinus node was located at the normal position over the junction of the superior vena cava and right atrium in patients 8 and 13. In patient 9 , 
two sinus nodes were found at the lower lateral portion of the right-sided atrium and at the middle dorsal portion of the left-sided atrium. In patient 12 the sinus node was at the lower dorsal portion of the left-sided atrium. In three patients (Nos. 14, 15, and 17), the sinus node was located at the lower portion of the atrium near the inflow of the hepatic vein, in patient 16 it was located at the root of the right-sided appendage, and in patient 11 it could not be detected because of junctional rhythm.

In eight patients with incomplete AVSD, atrial septal defect or common atrium was corrected with a single patch by moderate atrial septation. The two-patch method, which uses separate patches for septation of the atrium and closure of the VSD, was used in three patients with complete AVSD. Two patients with corrected TGA underwent a double switch operation, which was a combination of the Mustard operation applied as an atrial switch and of an internal conduit repair from the left ventricle through the VSD to the aorta as a ventriculoarterial switch. Another patient with corrected TGA underwent external conduit repair from the left ventricle to the pulmonary artery, with the right ventricle used as the systemic ventricle, because the atrial septum was shaped well and venous drainage was separated as in a situs inversus atrium. Obstruction of the right ventricular outflow tract in patients 6 and 9 was relieved by inserting a transannular patch with a monocusp.

In the presence of bilateral superior venae cavae, the vein without an azygos or hemiazygos connection was ligated except when the superior vena caval pressure rose more than $15 \mathrm{~mm} \mathrm{Hg}$ after clamping of the ipsilateral vessel. When ligation was impossible and reconstruction of the systemic venous return was required, different types of atrial septation were used. Atrial septation was classified into three groups (see Fig. 1).

\section{Results}

The mean duration of patient follow-up was $17.4 \pm 15.7$ months. All three patients with right isomerism survived the operation and all of them were in stable condition at the time of this report. One early death and two late deaths occurred among the 14 patients with left isomerism. Patient 6 , a 13-year-old boy with tetralogy of Fallot who had severe left ventricular dysfunction before the operation, died early after the operation. Patient 15 , who had AVSD and severe incompetence of the common AV valve, died of infection 3 months after the operation. Patient 5, who underwent a repair of corrected TGA, had an arrhythmia and died suddenly 18 months after the operation. Systemic venous obstruction developed in one patient with AVSD (patient 4), and the inflow opening for both cavae had to be enlarged with a patch 40 months after the initial operation. Severe mitral incompetence developed after the operation in patient 10 . The mitral valve was replaced by a $17 \mathrm{~mm}$ Carpen-
tier-Edwards prosthesis (Baxter Healthcare Corp., Edwards Div., Santa Ana, Calif.) on the seventeenth postoperative day.

Before the operation, 12 patients were in normal sinus rhythm. Junctional rhythm and atrial fibrillation were observed in two cases (patients 11 and 17, respectively). Three patients with congenital AV block had undergone permanent pacemaker implantation. Surgically induced complete AV block did not occur in any patient in this series. Postoperatively, normal sinus rhythm was maintained in three patients with right isomerism and seven patients with left isomerism. Of the other two patients who had sinus rhythm before the operation, one patient with left isomerism had a junctional rhythm immediately after the operation, and the other had sick sinus syndrome 18 months after the operation.

\section{Comment}

Biventricular repair is possible when the two ventricles are present, each has an adequate volume, and the anatomic relationship between the ventricles and AV valves is favorable. ${ }^{10,11}$ In our series, anatomic repair with the morphologically left ventricle used as the systemic ventricle was possible in 15 patients; in the other two patients (Nos. 1 and 5) we used the morphologically right ventricle for systemic circulation. Some studies ${ }^{12-15}$ have revealed disappointing late results with the correction of the morphologically right ventricle to support systemic circulation. Therefore patient 5 would currently be considered a candidate for anatomic repair with the double switch operation.

According to Di Donato and associates, ${ }^{16}$ palliative procedures, such as ligation of a patent ductus arteriosus or systemic-pulmonary artery shunt, should be performed initially in critically ill patients who are too small to undergo a radical operation. Biventricular repair is the procedure of choice, instead of a functional repair such as the Fontan operation, because the long-term results attained with functional repair are still controversial. ${ }^{17,18}$

The anatomic findings in the 93 patients with cardiac isomerism who had surgical treatment after 1985 are presented in Table II. Thirty-six percent of hearts with right isomerism and $72 \%$ of those with left isomerism had two ventricles. Two AV valves were present in $3 \%$ of the patients with right isomerism and $31 \%$ of those with left isomerism. Because of the presence of anomalies of ventriculoarterial discordance or total anomalous pulmonary venous connection, there were few good candidates 
Table II. Summary of anatomic findings

\begin{tabular}{|c|c|c|c|c|}
\hline & \multicolumn{2}{|c|}{$\begin{array}{c}\text { Right } \\
\text { isomerism } \\
(n=61)\end{array}$} & \multicolumn{2}{|c|}{$\begin{array}{c}\text { Left } \\
\text { isomerism } \\
(n=32)\end{array}$} \\
\hline & No. & $\%$ & No. & $\%$ \\
\hline UVH & 39 & 64 & 9 & 28 \\
\hline Two ventricles & 22 & 36 & 23 & 72 \\
\hline CAVV & 56 & 92 & 18 & 56 \\
\hline Two AV valves & 2 & 3 & 10 & 31 \\
\hline MA or TA & 3 & 5 & 4 & 13 \\
\hline VA concordance (Ao from LV) & 6 & 10 & 12 & 38 \\
\hline VA discordance (Ao from RV) & 55 & 90 & 20 & 62 \\
\hline Pulmonary atresia & 20 & 33 & 3 & 9 \\
\hline Pulmonary stenosis & 36 & 59 & 17 & 53 \\
\hline Bilateral SVC & 33 & 54 & 17 & 53 \\
\hline Right SVC & 24 & 39 & 10 & 31 \\
\hline Left SVC & 4 & 7 & 5 & 16 \\
\hline Right IVC & 43 & 70 & 11 & 34 \\
\hline Left IVC & 17 & 28 & 0 & \\
\hline IVC absence & 1 & 2 & 21 & 66 \\
\hline TAPVC & 37 & 61 & 2 & 6 \\
\hline PAPVC & 1 & 2 & 1 & 3 \\
\hline
\end{tabular}

$U V H$, Univentricular heart; $C A V V$, common atrioventricular valve; $A V$, atrioventricular; $M A$, mitral atresia; $T A$, tricuspid atresia; $V A$, Ventriculoarterial; $A o$, aorta; $L V$, left ventricle; $R V$, right ventricle; $S V C$, superior vena cava; $I V C$, inferior vena cava; $T A P V C$, total anomalous pulmonary venous connection; $P A P V C$, partial anomalous pulmonary venous connection.

for biventricular repair, especially in the case of patients with right isomerism. A functional repair was performed in patients with two ventricles when one of the ventricles was hypoplastic or when two competent $\mathrm{AV}$ valves could not be created. In this series, the ventricular volume was measured angiographically and indexed to the normal volume on the basis of the body surface area. ${ }^{19}$ The right ventricular volume ranged from $77 \%$ to $360 \%$ (mean 174\%) and the left ventricular volume from $83 \%$ to $370 \%$ (mean $170 \%$ ). The volume of both ventricles was more than $100 \%$ of normal in 12 patients.

Anomalies of systemic and pulmonic venous connections complicate the surgical procedures. Principles of repair include the division of any extracardiac communication and intracardiac separation of the venous return from pulmonary veins and systemic veins. ${ }^{20,21}$ Rerouting with baffles and use of the atrial switch with an equine pericardial patch are considered the most useful means of repair for isomeric hearts. ${ }^{11,22}$ Among our patients, one who had an AVSD was reoperated on to enlarge the vena caval orifices because stenotic lesions in the intraatrial baffle had developed. Long-term patency may be better attained with a tunnel reconstruction technique using an atrial septal flap or a prosthetic graft, rather than with the complicated atrial switch with baffles. ${ }^{23}$

Cardiac malformations associated with atrial isomerism include abnormalities of the conduction system. Congenital AV block has been reported to be more frequent in association with AVSD in left isomerism. ${ }^{24-27}$ Paired AV nodes were reported to be linked or potentially linked by a sling conduction tissue in isomeric hearts. ${ }^{26,27}$

We consider it advisable to locate the sinus node by intraoperative epicardial mapping. This reduces the risk of iatrogenic injury to the sinus node by caval cannulation or intraatrial manipulation. In patients with AVSD, the proper line of attachment of the baffle was difficult to ascertain, particularly when the coronary sinus ostium was absent. For such patients, endocardial mapping was attempted to identify the conduction pathway, but we did not have uniform success with this technique.

The clinical outcome in this series--early death in one patient and late death in two-was satisfactory when compared with the natural prognosis of these complex anomalies. The optimal surgical treatment for cardiac isomerism has not been established, but improved knowledge of the anatomy of these complex lesions will enhance the success of biventricular repair.

\section{REFERENCES}

1. Ivemark BI. Implications of agenesis of the spleen on the pathogenesis of cono-truncus anomalies in childhood: an analysis of the heart malformations in the splenic agenesis syndrome, with fourteen new cases. Acta Paediatr Scand 1955;44(Suppl 104):1-110.

2. Moller JH, Nakib A, Anderson RC, Edwards JE. Congenital cardiac disease associated with polysplenia. Circulation 1967;36:789-99.

3. Van Mierop LHS, Wiglesworth FW. Isomerism of the cardiac atria in the asplenia syndrome. Lab Invest 1962;11:1303-15.

4. Rose V, Izukawa T, Moes CAF. Syndromes of asplenia and polysplenia: a review of cardiac and noncardiac malformations in 60 cases with special reference to diagnosis and prognosis. Br Heart J 1975;37:840-52.

5. Becker AE, Anderson RH. Basic considerations. In: Crawford T, ed. Pathology of congenital heart disease. 1st ed. London: Butterworths, 1981:1-29.

6. Macartney FJ, Zuberbuhler JR, Anderson RH. Morphological considerations pertaining to recognition of atrial isomerism: consequences for sequential chamber localisation. Br Heart J 1980;44:657-67.

7. Soto B, Pacifico AD, Souza AS Jr, Bargeron LM Jr, 
Ermocilla R, Tonkin IL. Identification of thoracic isomerism from the plain chest radiograph. AJR Am J Roentgenol 1978;131:995-1002.

8. Sharma S, Devine W, Anderson R, Zuberbuhler JR. The determination of atrial arrangement by examination of appendage morphology in 1842 heart specimens. Br Heart J 1988;60:227-31.

9. Stumper OW, Sreeram N, Elzenga N, Sutherland GR. Diagnosis of atrial situs by transesophageal echocardiography. J Am Coll Cardiol 1990;16:442-6.

10. Sapire DW, Ho SY, Anderson RH, Rigby ML. Diagnosis and significance of atrial isomerism. Am $\mathrm{J}$ Cardiol 1986;58:342-6.

11. Marcelletti C, Di Donato R, Nijveld A, et al. Right and left isomerism: the cardiac surgeon's view. Ann Thorac Surg 1983;35:400-5.

12. Yagihara T, Kishimoto H, Kawashima Y, et al. Double switch operation in cardiac anomalies with atrioventricular and ventriculoarterial discordance. J THORac Cardiovasc Surg 1994;107:351-8.

13. McGrath L, Kirklin JW, Blackstone EH, Pacifico AD, Kirklin JK, Bargeron LM. Death and other events after cardiac repair in discordant atrioventricular connection. J Thorac Cardiovasc SuRg 1985;90:711-28.

14. Metcalfe J, Somerville J. Surgical repair of lesions associated with corrected transposition: late results. Br Heart J 1983;50:476-82.

15. Ramsay J, Venables AW, Kelly MJ, Kalff V. Right and left ventricular function at rest and with exercise after the Mustard operation for transposition of the great arteries. Br Heart J 1984;51:364-70.

16. Di Donato R, di Carlo D, Squitieri C, et al. Palliation of cardiac malformations associated with right isomerism (asplenia syndrome) in infancy. Ann Thorac Surg 1987;44:35-9.

17. Driscoll DJ, Offord KP, Feldt RH, Schaff HV, Puga
FJ, Danielson GK. Five- to fifteen-year follow-up after Fontan operation. Circulation 1992;85:469-96.

18. Fontan F, Kirklin JW, Blackstone EH, et al. Outcome after a "perfect" Fontan operation. Circulation 1990; 81:1520-36.

19. Kishimoto H, Hirose H, Kawashima Y, et al. Angiographic determination of right and left ventricular volumes and diameter of atrioventricular and semilunar valve rings in normal subjects. Shinzo 1985;17:711-6.

20. de Leval MR, Ritter DG, McGoon DC, Danielson GK. Anomalous systemic venous connection. Mayo Clin Proc 1975;50:599-610.

21. Rastelli GC, Rahimtoola SH, Ongley PA, McGoon DC. Common atrium: anatomy, hemodynamics, and surgery. J Thorac Cardiovasc Surg 1968;55:834-41.

22. Pacifico AD, Ricchi A, Bargeron LM, Colvin EC, Kirklin JW, Kirklin JK. Corrective repair of complete atrioventricular canal defects and major associated cardiac anomalies. Ann Thorac Surg 1988;46:645-51.

23. Sand ME, McGrath LB, Pacifico AD, Mandke NV. Repair of left superior vena cava entering the left atrium. Ann Thorac Surg 1986;42:560-4.

24. Wren C, Macartney FJ, Deanfield JE. Cardiac rhythm in atrial isomerism. Am J Cardiol 1987;59:1156-8.

25. Garcia OL, Mehta AV, Tamer DF, Ferrer PL, Wolff GS, Gelband H. Left isomerism and complete atrioventricular block: a report of six cases. Am J Cardiol 1981;48:1103-7.

26. Dickinson DF, Wilkinson JL, Anderson $\mathrm{KR}$, et al. The cardiac conduction system in situs ambiguous. Circulation 1979;59:879-85.

27. Ho SY, Fagg N, Anderson RH, Cook A, Allan LD. Disposition of the atrioventricular conduction tissues in the heart with isomerism of the atrial appendages: its relation to congenital heart block. J Am Coll Cardiol 1992;20:904-10. 